\title{
Hellenic "Death Race": The Emerging Greek RTA-Epidemic and its Similarities to Iranian RTAs
}

\author{
Gregory Tsoucalas ${ }^{1,2^{*}}$ \\ ${ }^{1}$ Hellenic Reference Centre for Alzheimer Disease and Related Dementia Syndromes, Neurology Clinic Agios Georgios, Alykes, \\ Volos, Greece \\ ${ }^{2}$ History of Medicine, Anatomy Department, School of Medicine, Democritus University of Thrace, Alexandroupolis, Greece
}

Corresponding Author: Gregory Tsoucalas, MD, PhD, Gregory Tsoucalas, lerolohiton 155, Agioi Anargyroi 38334, Volos, Greece. Email: gregorytsoucalas@yahoo.gr

Received August 20, 2018; Accepted September 9, 2018; Online Published September 30, 2018

\section{Dear Editor,}

A public health event occurred in our lives in 2009: the new H1N1 virus strain caused a word pandemic provoking 2900 deaths in Europe alone, while in Greece 149 people died, resulting in a wave of public fear boosted by both the mass media and medical societies. ${ }^{1}$ During the same oneyear period, 1463 died instantly after a series of road traffic accidents (RTAs) on Greek roads. However, neither the mass media, the scientific journals, nor the public healthcare system properly alerted the general population. Since 2009, about 1000 residents have been killed in Greece every year in an undeclared "road epidemic", 2 a condition presenting strong similarities with the situation in Iran, as noted by the Health Management Research Center of the University of Medical Studies in Tehran, Iran. ${ }^{3}$ Across Europe, an estimated 23,500 deaths per year are attributed to RTAs, with Greece being among the first afflicted in the European Union. Various types of RTAs every year in this Hellenic territory mark the zenith of this peculiar "epidemic pattern" (Figure 1).

High speed, alcohol, the complete absence of driving culture, a skimpy driving education, the inadequacy of police measures, aged drivers, and the lack of preventive measures ${ }^{2}$ have instigated a rise in severe public health issues; in addition to the dead, thousands of seriously wounded and disabled victims burden the Hellenic National Health Care System. Intensive care units are overwhelmed, and valuable resources and thousands of working hours are lost on a public health care system that is already traumatized by the economic crisis. RTAs are one of the leading causes of death, hospitalization, disability, and loss of resources. Road safety education programs combined with a series of other measures, such as driving tuition and law enforcement, should be implemented by the Greek state to raise awareness, minimize the incidence and severity of RTAs, and overturn this peculiar emerging epidemic. ${ }^{4}$ Moreover, advanced vehicle technology could be of significant help towards this end, with various assistant
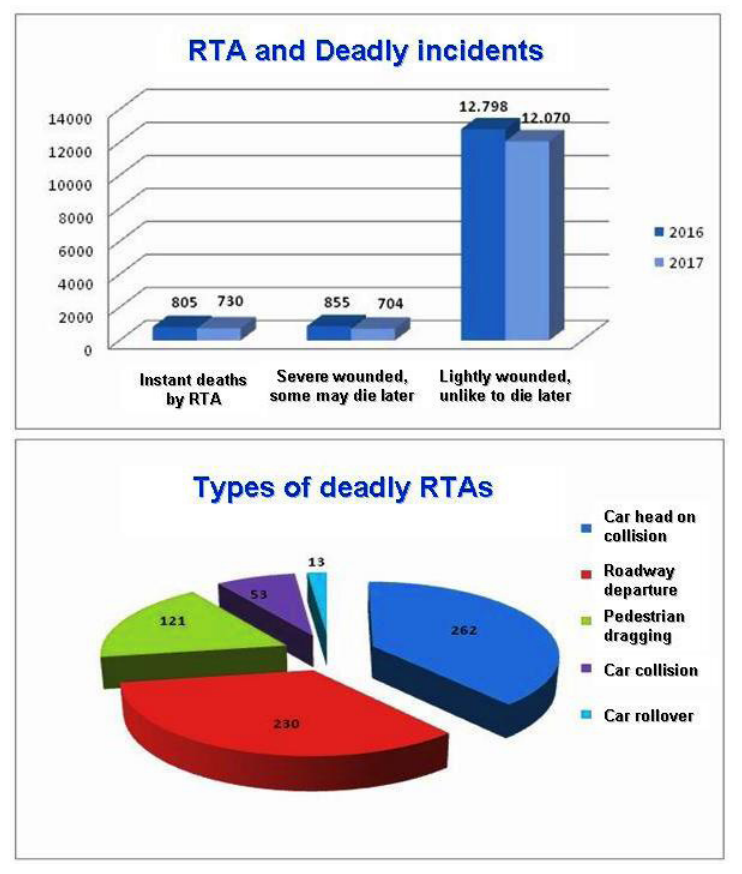

Figure 1. RTA and Deadly Incidents Per Year 2016/2017 and Types of Deadly RTAs

systems, such as the forward collision warning system, being installed in all types of road vehicles as a standard feature for the greatest social benefit. ${ }^{5}$

\section{Conflict of Interest Disclosures}

The author declares that he has no conflicts of interest.

\section{References}

1. Tsoucalas G, Sgantzos M. The 2009 influenza A virus subtype H1N1 pandemic, a glance from Greece. Infez Med. 2016;24(4): 259-264.

2. Information Management and Analysis Division of the Hellenic

Copyright $\odot 2018$ The Author(s). This is an open-access article distributed under the terms of the Creative Commons Attribution License (http:// creativecommons.org/licenses/by/4.0), which permits unrestricted use, distribution, and reproduction in any medium, provided the original work is properly cited. 
Traffic Police. http://www.astynomia.gr/statistics. Accessed November 7, 2018.

3. Meskarpour Amiri M, Bahadori M, Mehrabi-Tavana A. The dilemma of road traffic accidents in Iran. Int J Med Rev. 2017;4(3):91-92. doi:10.29252/ijmr-040307.

4. Mayhew D, Simpson H. Effectiveness and Role of Driver Education and Training in a Graduated Licensing System. Ottawa, Ontario: Traffic Injury Research Foundation; 1997.

5. Hubele N, Kennedy K. Forward collision warning system impact. Traffic Inj Prev. 2018 Sep 25:1-6. doi:10.1080/15389588.2018.1 490020

Citation: Tsoucalas G. Hellenic "Death Race": the emerging Greek RTA-epidemic and its similarities to Iranian RTAs. Int J Med Rev. 2018;5(3):135136. doi:10.29252/IJMR-050307. 